\title{
DAILY LYING BEHAVIOR PROFILE OF ONGOLE CATTLE THAT MAINTAINED INTENSIVELY
}

\author{
Sulistya Tri Agus* \\ Indonesian Beef Cattle Research Station, Indonesia \\ Isnaini Nurul, Susilawati Trinil \\ Faculty of Animal Husbandry, University of Brawijaya, Indonesia \\ *E-mail: bapakelintang@gmail.com
}

\begin{abstract}
The automation of monitoring livestock activities using various types of sensors is increasingly in various countries. The application of its technology in Indonesia still requires adjustment database, considering the Indonesia and the producer countries climate differences will affect the physiological and behavior of livestock. This research was made to get daily lying behavior profile of cows that on the luteal phase. That can be made into a database in cattle monitoring automation technology. A total of 8 healthy Ongole cows are placed in individual tied stall. Oestrus syncronizing was done to get luteal phase in all research materials. Lying duration recorded by Time Lapse Camera (TLC) at intervals of 2 minutes non-stop. Each photo has value 2 minutes duration and be tabulated by the Exceel 2010 software. Statistic parameter such as means, standard errors, standard deviations, kurtosis and skewness was calculated in the interval of 1 hour, 3 hours and 6 hours. The results showed that at the 1 hour interval, the highest lying behavior at 03.00 hours at 90.63 $\pm 17.60 \%$, the lowest at 08.00 hours at $5.99 \pm 13.55 \%$ and it has potential for alert activation at 3:00, 4:00, 5:00 and 8:00. The highest lying behavior duration on 3 hour intervals occurred at $03.00-06.00$ with $87.67 \%$, the lowest at $09.00-12.00$ with $19.79 \%$. At the 6 hour intervals, the highest lying behavior duration on $00.00-06.00$ hour intervals at $83.83 \pm 10.88 \%$, the lowest on 06.00-12.00 hour intervals at $15.48 \pm 15.48 \%$ and it has potential for alert activation at 00.00-06.00. The 6 hour interval is the most feasible to be chosen as the standard profile lying behavior, because it have the lowest standard deviation, which is $10.01 \%$.
\end{abstract}

\section{KEY WORDS}

Lying behavior, sensor, luteal phase, ongole.

The effort of animal activities monitoring automation technology on beef cattle and dairy cattle is growing rapidly all over the world. It is more applicable to high population livestock wich has limited time allocation of animal-human interaction. The use of sensors is a potential method to predict some animal activities such as feeding, ruminating, standing and lying behaviours of grazing beef cattle. However further research is needed to improve their ability to accurately estimate all behavioural activities and possibly evaluate their further use as health indicators (Poulopoulou, Lambertz, and Gauly 2019).

Several technology and methods for monitoring activities have been studied. (Barker et al. 2018) Used a combination of accelerator and General Positioning System (GPS) sensors wich tied on cow's neck and were able to record data in real time. It was concluded that there were significant differences by time of day with significantly lower mean total duration of feeding and higher total duration of nonfeeding in the afternoons for lame cows compared with nonlame cows. (Marchesini et al. 2018) used manufacturer sensor to record the duration of rumination and activity of cattle wich produced by the Heatime Pro System / HRLDn Tag; SCR Engineers and found that cows with low Average Daily Gain (ADG) have lower rumination duration compared with high ADG. The radio waves technology has also tested by (Wolfger et al. 2015) to detect Bovine Respiratory Disease (BRD) based on the results of 
cow's respiratory monitoring sensors. (Rombach et al. 2018) found that high accuracy in the use of rumination sensors and feeding time of cows using the Rumi Watch System, It was concluded that the use of sensors has the potential to be developed with improvements to the algorithm and software.

The use of automation sensors technology in Indonesia is limited to adopt outside technology then directly applied on local livestock. It will reduce the accuracy of detection, due to climate differences between Indonesia and the country where the device was developed. On other hand, some micro climatic factors such as temperature, humidity, radiation and wind speed was affect livestock productivity (Yani and Purwanto 2006). With the result that environment will affect animal behavior patterns which are used as the parameters of various automation sensor devices.

The aim of this study was to get a database of the daily lying behavior duration profile of Ongole cattle wich maintained intensively in the luteal phase. The daily lying behavior duration profile is expected to be the result of uniformity behavior data that, so it can be used as a standard profile of daily lying behavior on luteal phase. The standard profile is possible to detect non-luteal cattle (follicular and oestrus), especially if the non-lutheal phase has a different profile. So that, this standard profile will be useful for health monitoring automation systems development as well as cow's hormonal changes based on lying behavior in Indonesia.

\section{MATERIALS AND METHODS OF RESEARCH}

Time and Place. The study was conducted at the Indonesian Beef Cattle Research Station, Ministry of Agriculture in Pasuruan Regency-East Java. The study was conducted for two months (October - November) 2019. A total of 8 cows PO cattle with normal reproductive and not in pregnant had been placed on individual tied stall for 24 hours. It has a width of 125 $\mathrm{cm}$. Each individual stall is equipped with a water feed bucket. In each row of individual stall are given 50 Watt fluorescent lighting, to get clearly photos at night.

Maintenance. The cows were given standard treatment maintenance of the Beef Cattle Research Station for non-pregnant cows. King grass chopped forage provided in the bucket as much as 5-8 kg/day. Concentrate feed ("NU Feed" type Big Geny for beef cattle broodstock) was given on the bucket, while the nutritional specifications are $14 \%$ protein, $6 \%$ fat, maximum 35\% NDF, minimum TDN 65\%, maximum ash $12 \%$ and maximum water content $13 \%$. Concentrate is given as much as $4-5 \mathrm{~kg} /$ day. The workers of research station start their activities at 6:30 a.m. The work order of the workers is stall cleaning, feed bucket cleaning, cow's body spraying, giving forage and concentrate. Time breaks for the worker are from 11:30 up to 13:00.

Temperature and Humidity Recording. The temperature and humidity of the environment are recorded by RC-4HA / 4HC Temperature and Humidity Date Logger from Elitech Technology Inc. made in China. Temperature and humidity are recorded automatically by the device every hour. Temperature and humidity data transferred to the Personal Computer for tabulation. Tabulation and calculation of the mean, standard error, standard deviation, kurtosis and skewness were performed by the Microsoft Excel 2010 program. Data are presented in graphical form.

Temperature Humidity Index (THI). THI is an index to measure the comfort level of livestock environment. THI is obtained from the interaction of the temperature and humidity of the air. THI calculations use the following mathematical model (Bulitta, Aradom, and Gebresenbet 2015):

$$
\begin{gathered}
\mathrm{THI}=0.8 \mathrm{~T}+\mathrm{RH}(\mathrm{T}-14.4)+46.4 \\
\mathrm{THI}=\text { Temperature Humidity Index; } \\
\mathrm{T}=\text { ambient temperature }\left({ }^{\circ} \mathrm{C}\right) ; \\
\mathrm{RH}=\text { Humidity }(\%) .
\end{gathered}
$$

Stress levels that can be received by ruminants are calculated using the Temperature Humidity Index (THI) shown on table 1. 
Table 1 - Temperature Humidity Index categories

\begin{tabular}{ll}
\hline THI score & Categories \\
\hline$<74$ & Normal \\
$75-78$ & Alert \\
$79-83$ & Danger \\
$>84$ & Emergency \\
\hline
\end{tabular}

Source: (Bulitta, Aradom, and Gebresenbet 2015).

Oestrus Syncronize. Oestrus syncronize was done to equalize the ovarium cycle to luteal phase. Oestrus synchronze was carried out using the 2 times injection methode of the Prostaglandin F2 alpha hormone which was repeated on the $11^{\text {th }}$ day (Efendi et al. 2015). The hormone wich used is trademarked "Alfaglandin" produced by Alfasan Woerden-Holland (exp. Date: $07-2021$ ) with a content of cloprostenol $250 \mathrm{mcg} / \mathrm{mL}$. Cows are given a hormone injection at a dose of $2 \mathrm{~mL} / \mathrm{cow}$ on subcutaneous and repeated on day $11^{\text {th }}$. Oestrus sign appear after days $12^{\text {th }}$ up to $17^{\text {th }}$ (Oestrus-1). When the cow enters the next lutheal phase (luteal-2), a recording of the cow's lying behavior was recorded. The determination of the luteal phase used the calculation of $5^{\text {th }}$ days to $16-17^{\text {th }}$ after signs of Oestrus occurs (Yekti et al. 2017).

\section{RESULTS AND DISCUSSION}

Temperature Humidity. Temperature and humidity are micro climatic factors which are included in environmental conditions that cannot be controlled (Susilawati and Yekti 2018). Both of these factors can affect livestock production, because they can cause changes in heat balance in the body, water balance, energy balance and balance of livestock behavior (Esmay 1969). The results of automatic recording of the Temperature and Humidity Date Logger during the study are presented in Table 2 . The lowest temperature was recorded at $04.00 \mathrm{am}$ with a temperature of $24.8 \pm 1.24^{\circ} \mathrm{C}$ and the highest temperature at 12.00 with a temperature of $33.9 \pm 0.56^{\circ} \mathrm{C}$. The daily temperature of the stall during the research has a natural change for the tropics fluctuation pattern. Even though it looks high, the temperature is still within the normal temperature range for the Indonesian climate which has a temperature range between $24^{\circ} \mathrm{C}-34^{\circ} \mathrm{C}$ with $60-90 \%$ humidity (Yani and Purwanto 2006). Cattle wich used as research material are multi paraous female cows that have an age more than 5 years. The data records have shown that cow productivity was not disturbed by the fluctuation temperature which the study was conducted. So, the data of lying behavior wich have recorded in the study was a normal cow behavior pattern.

Table 2 - Average temperature, humidity and temperature humidity index during the study

\begin{tabular}{|c|c|c|c|c|c|c|c|c|c|c|c|c|c|c|c|c|c|c|c|c|c|c|c|c|}
\hline $\begin{array}{l}\text { Jam } \\
\text { Tomn }\end{array}$ & 0 & 1 & 2 & 3 & 4 & 5 & 6 & 7 & 8 & 9 & 10 & 11 & 12 & 13 & 14 & 15 & 16 & 17 & 18 & 19 & 20 & 21 & 22 & 23 \\
\hline $\begin{array}{l}\text { Tempage } \\
\text { atd dev }\end{array}$ & $\begin{array}{l}26,4 \\
1,10\end{array}$ & $\begin{array}{l}25,9 \\
1,13\end{array}$ & $\begin{array}{l}25,5 \\
1,24\end{array}$ & $\begin{array}{l}25,1 \\
1,29\end{array}$ & $\begin{array}{l}24,8 \\
1,24\end{array}$ & $\begin{array}{l}25,8 \\
1,17\end{array}$ & $\begin{array}{l}28,0 \\
0,89\end{array}$ & $\begin{array}{l}29,6 \\
0,55\end{array}$ & $\begin{array}{l}31,1 \\
0,42\end{array}$ & $\begin{array}{l}32,5 \\
0,55\end{array}$ & $\begin{array}{l}33,4 \\
33,50\end{array}$ & $\begin{array}{l}33,7 \\
0,54\end{array}$ & $\begin{array}{l}33,9 \\
0,56\end{array}$ & $\begin{array}{l}33,4 \\
0,64\end{array}$ & $\begin{array}{l}32,9 \\
0,75\end{array}$ & $\begin{array}{l}32,0 \\
0,59\end{array}$ & $\begin{array}{l}31,0 \\
0,48\end{array}$ & $\begin{array}{l}30,3 \\
0,39\end{array}$ & $\begin{array}{l}29,6 \\
0,26\end{array}$ & $\begin{array}{l}29,1 \\
0,37\end{array}$ & $\begin{array}{l}28,6 \\
0,36\end{array}$ & $\begin{array}{l}27,9 \\
0,51\end{array}$ & $\begin{array}{l}27,3 \\
0,72\end{array}$ & $\begin{array}{l}26,8 \\
0,92\end{array}$ \\
\hline $\begin{array}{l}\text { average } \\
\text { Std dev }\end{array}$ & $\begin{array}{l}80,7 \\
1,73\end{array}$ & $\begin{array}{l}81,6 \\
2,30\end{array}$ & $\begin{array}{l}82,9 \\
1,73\end{array}$ & $\begin{array}{l}83,9 \\
1,57\end{array}$ & $\begin{array}{l}84,7 \\
1,48\end{array}$ & $\begin{array}{l}83,4 \\
2,66\end{array}$ & $\begin{array}{l}75,4 \\
5,37\end{array}$ & $\begin{array}{l}70,6 \\
5,24\end{array}$ & $\begin{array}{l}65,8 \\
6,80\end{array}$ & $\begin{array}{l}58,7 \\
6,45\end{array}$ & $\begin{array}{l}57,6 \\
5,25\end{array}$ & $\begin{array}{r}56,5 \\
4,19\end{array}$ & $\begin{array}{r}54,8 \\
4,92\end{array}$ & $\begin{array}{l}55,1 \\
4,72\end{array}$ & $\begin{array}{l}56,8 \\
4,74\end{array}$ & $\begin{array}{l}60,4 \\
6,63\end{array}$ & $\begin{array}{l}64,2 \\
8,00\end{array}$ & $\begin{array}{l}66,8 \\
5,48\end{array}$ & $\begin{array}{l}69,4 \\
7,94\end{array}$ & $\begin{array}{r}71,6 \\
8,00\end{array}$ & $\begin{array}{l}73,6 \\
6,58\end{array}$ & $\begin{array}{l}76,4 \\
5,15\end{array}$ & $\begin{array}{r}78,4 \\
3,06\end{array}$ & $\begin{array}{l}79,6 \\
2,12\end{array}$ \\
\hline $\begin{array}{l}\text { sore } \\
\text { score }\end{array}$ & 77.2 & 76.6 & 76.0 & 75.5 & 75.1 & 76.6 & 79.1 & 80.9 & 82.2 & 83.0 & 84.0 & 84.3 & 84.2 & 83.6 & 83.2 & 82.6 & 81.9 & 81.2 & 80.6 & 80.2 & 79.7 & 79.0 & 78.3 & 77.7 \\
\hline
\end{tabular}

The difference of temperature during the study on each hour on table 2 is normaly, indicated by the value of the standard deviation $\left(<3^{0} \mathrm{C}\right)$. The highest standard deviation recorded is $1,29^{\circ} \mathrm{C}$ at 03.00 . It was saw that each hour of the day there was no extreme temperature difference. The research material wich used on this study was Ongole cattle come under Bos Indicus cattle. (Beatty et al. 2006) had prove that physiological of Bos Indicus is more tolerant of temperature fluctuation compared to Bos Taurus cattle on; food intake, drinking intake, blood acidity and respiratory rate. In other words the daily lying behavior profile wich recorded during this study can be calculated on it's average, because it is not influenced by temperature fluctuations each days. A chart of daily temperature changes is presented in Figure 1. The trend of temperature changes is reaching maximum point between 11.00 to 13.00 . Then the trend move slowly down to reach the lowest point at 3:00 to 5:00 in the morning, and then move up again. 


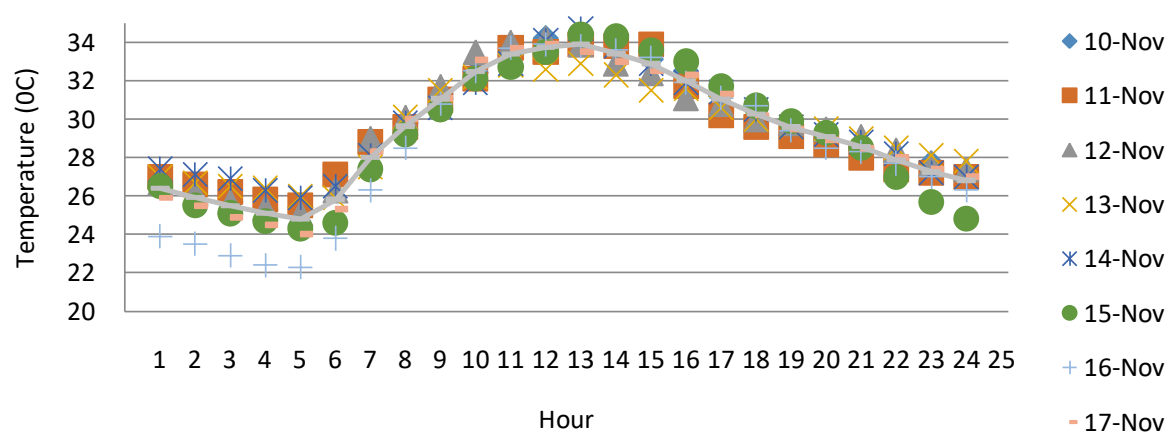

Figure 1 - Daily temperature changes

The humidity was recorded on this study is relative (\%) humidity. This humidity can be understood as a percentage of the water that available at the time of recording compared to the maximum water vthat can be contained by the air at that time. The maximum humidity of the stall was recorded at 3:00 a.m. with a value of $84.7 \pm 1.48 \%$ and the minimum humidity occurred at 13.00 p.m. with a value of $54.8 \pm 4.92 \%$. The difference in humidity during research days at each time can be seen from the standard deviation values. The higest standard deviation occurred at 19:00 p.m. by $8 \%$. This can be said to be reasonable, the research held in November (the peak of the dry season) and there was a considerable wind transition, so that was affected the humidity between days. The trends of daily humidity changes can be seen in Figure 2. The trend of humidity changes is in accordance with the explanation of the results of research (Suherman et al. 2013). The movement of the humidity graph is reversed with the trend of daily temperature changes where the sun is at the peak accompanied by the temperature peak and then the humidity is at its lowest point.

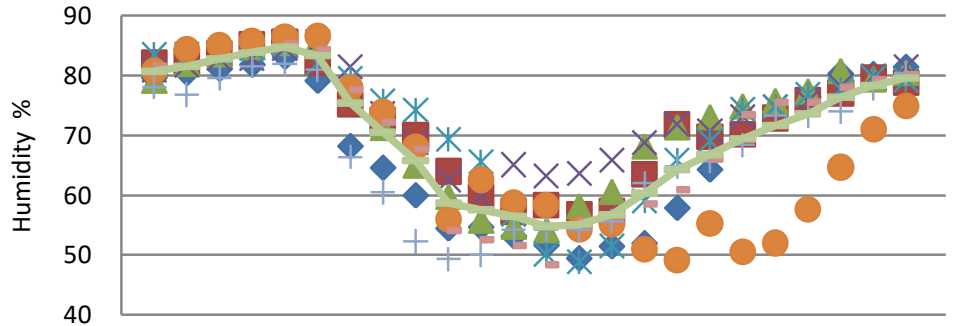

$142 \quad 3 \quad 4 \quad 5 \quad 6 \quad 7 \quad 8 \quad 910111213141516171819202122232425$

Hour

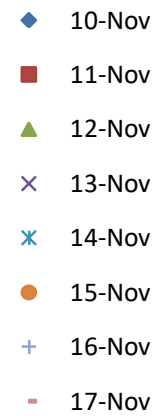

Figure 2 - Daily humidity changes

Temperature Humidity Index. The Livestock Weather Safety Index or LWSI is a indicator that commonly used to measure livestock stress levels due to temperature, and it is divided into several categories; normal, alert, dangerous and emergency. The stress level calculation is clasified using THI formulas which calculated based on temperature and humidity values (NOAA 1976). The daily THI score of the stall environment during the study are presented in Figure 3. The average daily THI score reaches the lowest score where the cow does not get heat stress at 04.00 a.m. with a score of 75.1 and the highest heat stress at 11.00 a.m. with a THI value of 84.3. (Nuriyasa, Dewi, and Budiari 2015) reported that the score of THI at the Bali lowland feedlot farms reached 73.24 where the location is similar with the location of the study.

Based on the classification of the THI score, the research material cows experiencing got "alert" stress level in the early morning and going up to danger conditions during the day, even at certain hours touching emergency criteria. This can be understood because the 
research was held in November, where normally it has entered the rainy season, but at the time of the study in November 2019 the rainy season had not yet entered so the weather conditions (temperature) were at their peak. The high THI level at the study was not something dangerous to livestock conditions, because the study of (Sapi et al. 2018) wich used dairy cows, concluded that although it was indicated that THI affected the comfort zone of livestock in his research, there was no positive correlation between the level of THI and the level of cow reproductive efficiency.

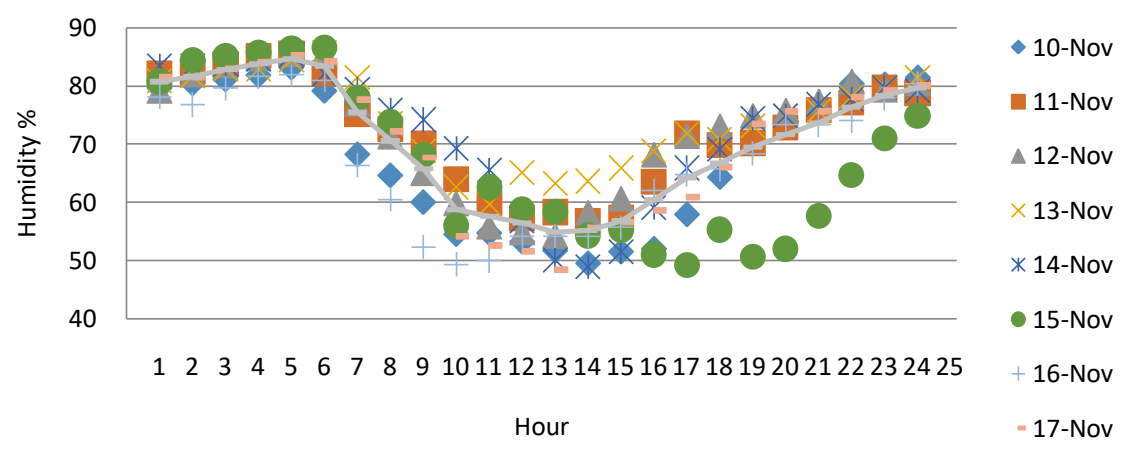

Figure 3 - Temperature Humidity Index change

Daily Lying Behavior. The daily lying behavior profile was taken in this study is during the luteal phase of the estrous cycle. The luteal phase begins at the end of Met estrus (5 days after oestrus) where Corpus hemorrhagic begins to turn into lutheal tissue phase and ends on days 16-17 which is marked by the start of the Corpus Lutheum regression process (Yekti et al. 2017). The choice of luteal phase in this study was due to the fact that the reproductive hormones were stable; the progesterone hormone was at its peak while the Follicle Stimulatig Hormone (FSH), Leutenizing Hormone (LH) and Estrogen in the lowest conditions. It is expected that the duration profile of lying behavior recorded was not affected by hormonal changes. The variations of the first oestrus cycle duration in research caused the second oestrus after synchronize was not in conformity. This condition caused the beginning to enter the $2^{\text {nd }}$ luteal phase not conformity too and only obtained 8 days from 8 cows encounter luteal phase together. From these conditions the profile data of lying behavior obtained 64 daily data. Daily lying behavior profile in the form of a bar chart at each observation interval ( 1 hour, 3 hours and 6 hours) with a standard error presented in Fig. 4-6.

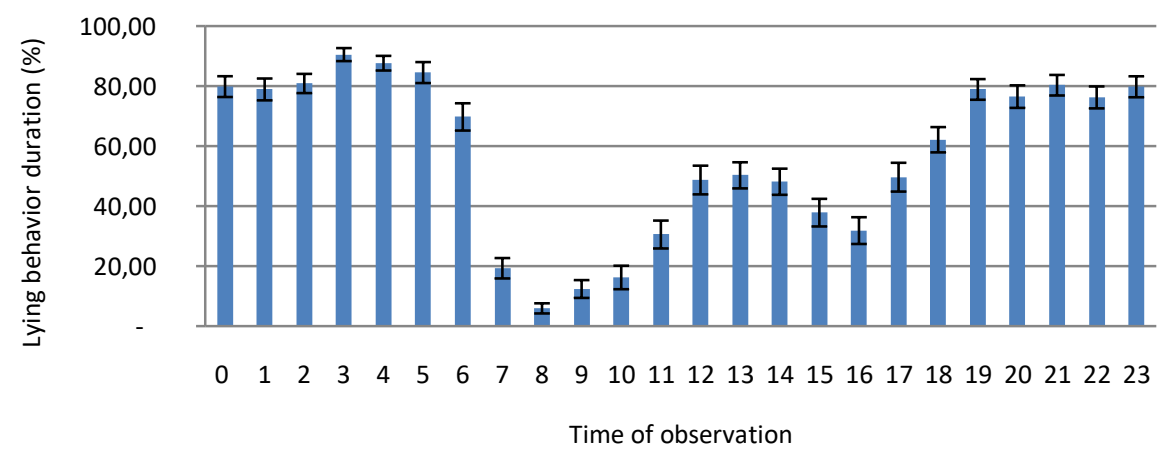

Figure 4 - Profile of daily lying behavior on each hour

The standard error values that displayed at each observation interval ( 1 hour, 3 hours and 6 hours) indicate the predicted range of the overall population average. The low standard error value allows the profile obtained can be used as a standard profile that would be used as a reference for activating alerts (if there is a data difference between luteal and 
non-luteal phase). If it is proven that there are differences in lying behavior data between luteal and non-luteal cows, the activation of the alert should be accurate and as fast as possible. To get the fast calculation and accuracy, several other statistical parameters are needed as a basis for calculation.

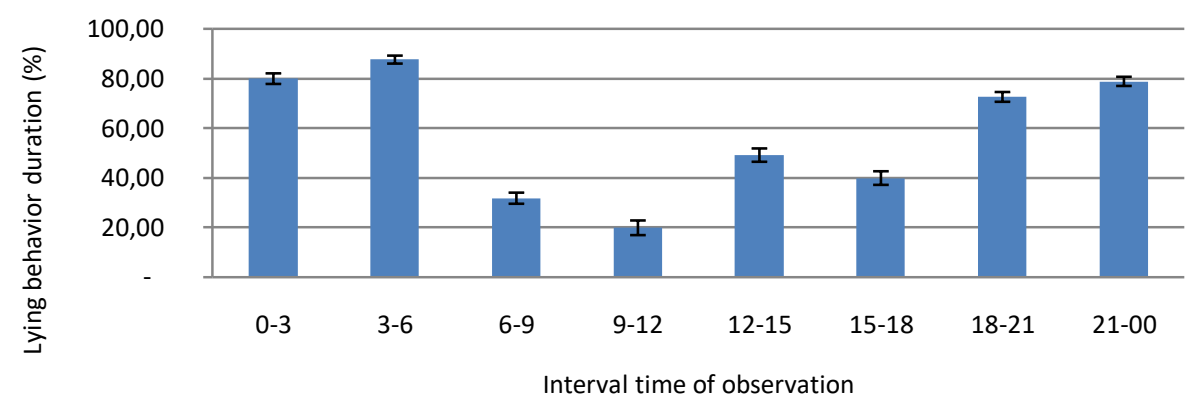

Figure 5 - Profile of daily lying behavior on 3 hours interval

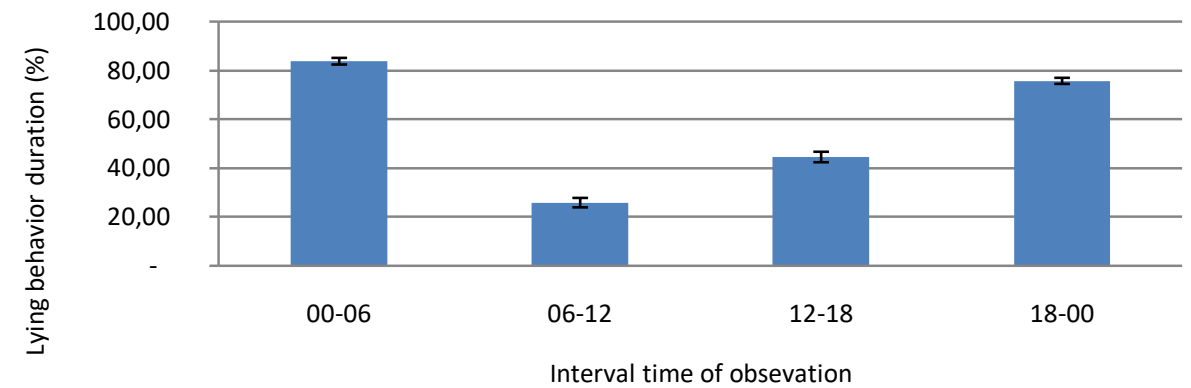

Figure 6 - Profile of daily lying behavior on 6 hours interval

Some descriptive statistical parameters wich used to analyze the daily lying behavior profile are standard deviation, error standard, kurtosis and skewness. Daily lying behavior data that was completed with descriptive parameters at each observation interval are presented in Table 2. Mean value shown the average value of 64 data was obtained. If the data is normally dispersed, then the standard deviation can be interpreted that $68.27 \%$ of the data was at the mean \pm standard deviation (Spiegel 1961). The error standard describes the average distribution of the sample on the average of the overall sample possibilities (population). Kurtosis is a shape of curve, where the more homogeneous data will be more tapered and formed leptokurtis (Supranto 2009).

Table 3 - Lying behavior duration on each interval

\begin{tabular}{|c|c|c|c|c|c|c|c|c|c|c|c|c|c|c|c|c|c|c|c|c|c|c|c|c|}
\hline $\begin{array}{l}\text { Intranal } \\
\text { hlourr) }\end{array}$ & 0 & 1 & 2 & 3 & 4 & 5 & 6 & 7 & 8 & 9 & 10 & 11 & $\begin{array}{l}12 \\
\end{array}$ & 13 & 14 & 15 & 16 & 17 & 18 & 19 & 20 & ${ }^{21}$ & 22 & 23 \\
\hline 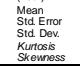 & $\begin{array}{l}79.95 \\
3.97 \\
27.78 \\
0.129 \\
(i .25) \\
\end{array}$ & $\begin{array}{l}79.01 \\
2.941 \\
29.76 \\
(1.64) \\
(1.64)\end{array}$ & 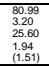 & $\begin{array}{l}20.63 \\
217.39 \\
7.75 \\
7.264) \\
2.644\end{array}$ & 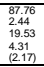 & 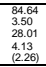 & 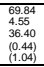 & 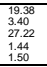 & $\begin{array}{l}5.99 \\
1.99 \\
1.55 \\
6.44 \\
2.46 \\
\end{array}$ & 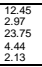 & $\begin{array}{l}16.30 \\
\text { 3.9. } \\
\text { 3.1.33 } \\
\text { 2.52 } \\
1.95 \\
\end{array}$ & $\begin{array}{l}30.63 \\
\text { 3.6. } \\
37.21 \\
10.83 \\
0.82\end{array}$ & 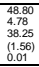 & 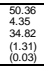 & 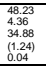 & 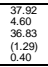 & $\begin{array}{l}3.9 .93 \\
43.73 \\
10.77 \\
0.77 \\
\end{array}$ & 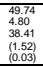 & 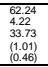 & $\begin{array}{l}79.01 \\
3.45 \\
2.7 .59 \\
0.138 \\
(i .17) \\
\end{array}$ & $\begin{array}{l}7.6 .66 \\
3.06 \\
0.06 \\
0.80 \\
1.36) \\
\end{array}$ & $\begin{array}{l}83.42 \\
\text { 32.43 } \\
27.14 \\
(1.46) \\
\end{array}$ & 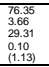 & 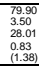 \\
\hline 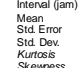 & $\begin{array}{l}0.0033 \\
79.98 \\
1.71 .10 \\
6.58 \\
6.592\end{array}$ & & & 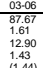 & & & $\begin{array}{l}\frac{06.99}{3174} \\
\text { 2.24 } \\
17.93 \\
0.577\end{array}$ & & & $\begin{array}{l}\frac{091212}{19.79} \\
2.96 \\
23.68 \\
0.76\end{array}$ & & & $\begin{array}{l}\frac{12.15}{49.13} \\
2.69 \\
21.53 \\
0.39\end{array}$ & & & 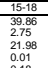 & & & $\begin{array}{l}\frac{18.21}{72.62} \\
19.85 \\
1.105\end{array}$ & & & $\begin{array}{l}21.23 \\
7.89 \\
1.8 .80 \\
1.190\end{array}$ & & \\
\hline 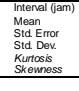 & \begin{tabular}{l|l}
$0.0-06$ \\
1.33 \\
1.36 \\
0.08 \\
0.21 \\
0.811 \\
\end{tabular} & & & & & & $\begin{array}{l}25.72 \\
25.76 \\
19.48 \\
0.499 \\
0.24 \\
\end{array}$ & & & & & & $\begin{array}{l}12.18 \\
44.50 \\
2.15 \\
17.20 \\
0.39 \\
(0.41)\end{array}$ & & & & & & $\begin{array}{l}18.23 \\
7.576 \\
1.25 \\
10.01 \\
0.025) \\
0.488\end{array}$ & & & & & \\
\hline
\end{tabular}

Skewness is the slope of the curve, where on the standard curve the values between modes, averages and medians are on the same range. The curve will be tilt form if there is a range or modes, average and medians (Supranto 2009). Based on the parameters wich used on its calculation in order to get accuracy alert, several parameter such as low standard deviation, positive value of kurtosis, and normal skewness.

At the hourly observation interval, the lowest value of lying duration occurred at 08.00 with $5.99 \%$ and the highest at 03.00 with $90.63 \%$. This can be understood because in the 
morning from $07.00-08.00$ is the hour of feeding activities, so that the all of cows was in a standing position to feed. While at 3:00 a.m. the most of cows was in a lying position. At the 03.00 and 08.00 a.m. the skewness value shows the lowest (negative) and highest (positive) value, its mean that the distribution of data is getting skewed because under these conditions the mean value is close to $100 \%$ or $0 \%$ so that it is impossible to get a normal curve.

The standard deviation at one hour interval is still relatively high $(13.55 \%-38.25 \%)$ when it compared to other observation intervals ( 3 hours and 6 hours). The standard deviation is understandable that $68.27 \%$ of the data is on the range of mean \pm standard deviation (Spiegel 1961), then the accuracy of using 1 hour intervals as activation alerts will be lower than other intervals ( 3 hours and 6 hours). The value of kurtosis as indicator of data distributions, then at 8 a.m. there is a tendency for data to be more in uniform shape so the data distribution curve at that hour tends to taper with a kurtosis value of 6.14 followed by 03:00,04:00 and 05:00 at 7.85; 4.31 and 4.13. It is shows that at these hours there is an opportunity to be used as an alert avtivation because of the more uniform distribution of data. Thus, potential alert activation for 1 hour observation intervals are at 3:00, 4:00, 05:00 and 08:00 in the morning even with a high standard deviation level $(13.55 \%-38.25 \%)$.

The duration of lying behavior at 3 hour interval observation shows the highest value at 03:00-06:00 hour intervals with a value of $87.67 \%$ and the lowest value at 09:00-12:00 hour intervals with a value $19.79 \%$. The 3 hour observation interval has a lower standard deviation value than the 1 hour interval and it is still higher than the 6 hour observation interval. The 3 hours interval, the highest value of kurtosis is at 00.00-03.00 at 6.58 which means that the data distribution curve at the observation interval is very uniform. This interval has the potential to be activation alert on the automation system.

The duration of daily lying behavior on 6 hours interval obsevation shows the highest value on $00.00-06.00 \mathrm{a} . \mathrm{m}$. at $83.83 \%$ and the lowest value on $06.00-12.00$ interval at $25.76 \%$. When compared with the study of (Poulopoulou, Lambertz, and Gauly 2019) who obtained the duration of lying behavior for 8 Holstein cows was 45.5 minutes/hour or $75 \%$ at night and 10.8 minutes/hour or $17 \%$ during the day. It is mean that the results of this study is not too different.

The standard deviation at the 6 hour interval observation dropped to $(10.01 \%-17.2 \%)$ and it is the smallest standard deviation value compared to other observation intervals (1 hour and 3 hours). The low standard deviation value illustrates the behavior of livestock on 6 hours interval more uniformly than the other intervals (1 hour and 3 hours). At the interval 00.00-06.00 has the smallest standard deviation value and the value of kurtosis is close to zero or the data dispersion curve tends to be normal, this makes the calculation of behavior at 00.00-06.00 has the potential to be a activation alerts. On the application, if there is a difference of data more than the standard deviation value $(10.01 \%)$, and it is used as a basis for the activation of alerts on the automation system, the accuracy of its alert has reached $68.2 \%$. In terms of minutes duration, activation alerts will be activate if there is a difference in the duration of lying behavior more than 61 minutes above or below the value on the standard profile. Accuracy can be increased up to $95.4 \%$ by adding the alert activation limit to $2 \times$ the standard deviation or by 122 minutes above or bellow than the standard profile. The disadvantage of using its interval is the long calculation duration, so that the result of calculation to activate alerts on the sensor can only be done once every 6 hours, or 4 times/day.

Closest possibility of the lying behavior standar profile that has been obtained is to develop the cow activity monitoring technology are lamenes cow monitoring. (Barker et al. 2018) has identified several previous studies and stated that sensor lying behavior individually has the potential to be a lamenes cow monitoring. Research of (Silper et al. 2015) found that the average non-oestrus cow's footstep was 99 steps/hour and increased up to 343 steps/hour during oestrus. If the increasing activity of oestrus cow was hampered by tied stall and just expressed by standing behavior, the lying behavior profile was potentially becomes automation oestrus sensor database. 


\section{CONCLUSION}

The cow daily lying behavior on the luteal phase wich maintained intensively can be made into standar profile database of automation oestrus sensor technology. Based on statistical parameters on each observation interval has a potential to be a marker of activation alerts. At 1 hour observation, the potential for activation alerts occurs at 03.00 , $04.00,05.00$ and 08.00 a.m. At 3 hour observation intervals, the potential for activation alerts occurs at 00.00-03.00 a.m interval. At 6 hour intervals of observation, the potential for activation alerts occurs at 00.00-06.00 interval. The 6 hour interval observation is more feasible, because it has the lowest standard deviation value $10.01 \%$. The lying behavior profile is potential to be able to detect hormonal changes. It can be done if there is a difference on the lying behavior greater or smaller 61 minutes from the standard profile at the observation hour 00.00-06.00 a.m. The activation of the alert has an accuracy of $68.2 \%$. Accuracy can be increased up to $95.4 \%$ if the difference is more or less than 122 minutes from the standard profile.

\section{ACKNOWLEDGEMENTS}

The authors would like to thank the Agriculture Ministry of Indonesia as funder of the study, and the Brawijaya University for their cooperation in this study.

\section{REFERENCES}

1. Barker, Z. E., J. A. Vázquez Diosdado, E. A. Codling, N. J. Bell, H. R. Hodges, D. P. Croft, and J. R. Amory. 2018. "Use of Novel Sensors Combining Local Positioning and Acceleration to Measure Feeding Behavior Differences Associated with Lameness in Dairy Cattle." Journal of Dairy Science 101 (7). American Dairy Science Association: 6310-21. doi:10.3168/jds.2016-12172.

2. Beatty, D T, A Barnes, E Taylor, D Pethick, M McCarthy, and S K Maloney. 2006. "Physiological Responses of Bos Taurus and Bos Indicus Cattle to Prolonged, Continuous Heat and humidity1." Journal of Animal Science 84 (4): 972-85. doi:10.2527/2006.844972x.

3. Bulitta, Fufa Sorri, Samuel Aradom, and Girma Gebresenbet. 2015. "Effect of Transport Time of up to 12 Hours on Welfare of Cows and Bulls." Journal of Service Science and Management 8 (2): 161-82. doi:10.4236/jssm.2015.82019.

4. Efendi, M, T N Siregar, C N Thasmi, and A Sayuti. 2015. "DENGAN PROTOKOL OVSYNCH Conception Rates of Local Cows after Induction with Ovsynch Protocols." Jurnal Medika Veterinaria 9 (2): 159-62.

5. Esmay, Merle L. 1969. "Principles of Animal Environment." Principles of Animal Environment. Westport, Conn.: Avi Publishing Co., Inc.

6. Marchesini, Giorgio, Davide Mottaran, Barbara Contiero, Eliana Schiavon, Severino Segato, Elisabetta Garbin, Sandro Tenti, and Igino Andrighetto. 2018. "Use of Rumination and Activity Data as Health Status and Performance Indicators in Beef Cattle during the Early Fattening Period." Veterinary Journal 231. Elsevier Ltd.: 41-47. doi:10.1016/j.tvjl.2017.11.013.

7. NOAA. 1976. "Livestock Hot Weather Stress. Operations Manual Letter 1976; C-3176." NOAA Kansas City, MO.

8. Nuriyasa, I. M., G. A. M. K Dewi, and N. L. G. Budiari. 2015. "Indeks Kelembaban Suhu and Respon Fisiologi Sapi Bali Yang Dipelihara Secara Feed Lot Pada Ketinggian Berbeda." Majalah IImiah Peternakan 18 (1): 5-10. doi:10.24843/mip.2015.v18.i01.p02.

9. Poulopoulou, loanna, Christian Lambertz, and Matthias Gauly. 2019. "Are Automated Sensors a Reliable Tool to Estimate Behavioural Activities in Grazing Beef Cattle?" Applied Animal Behaviour Science 216 (March). Elsevier: 1-5. doi:10.1016/j.applanim.2019.04.009.

10. Rombach, M., A. Münger, J. Niederhauser, K. H. Südekum, and F. Schori. 2018. 
"Evaluation and Validation of an Automatic Jaw Movement Recorder (RumiWatch) for Ingestive and Rumination Behaviors of Dairy Cows during Grazing and Supplementation." Journal of Dairy Science 101 (3): 2463-75. doi:10.3168/jds.201612305.

11. Sapi, Reproduksi, Kabupaten Bogor, Dadang Jaenudin, Akhmad Arif Amin, Mohamad Agus Setiadi, and Hadi Sumarno. 2018. "Hubungan Temperatur, Kelembaban, and Manajemen Pemeliharaan ( Correlation of Temperature, Humidity, and Livestock Management" 6 (1): 16-23.

12. Silper, B. F., I. Robles, A. M.L. Madureira, T. A. Burnett, M. M. Reis, A. M. de Passillé, J. Rushen, and R. L.A. Cerri. 2015. "Automated and Visual Measurements of Estrous Behavior and Their Sources of Variation in Holstein Heifers. I: Walking Activity and Behavior Frequency." Theriogenology 84 (2). Elsevier Inc: 312-20. doi:10.1016/j.theriogenology.2014.12.029.

13. Spiegel, Murray Ralph. 1961. "Schaum's Outline of Theory and Problems of Statistics." McGraw-Hill.

14. Suherman, D., B. P. Purwanto, W. Manalu, and I. G. Permana. 2013. "Model Penentuan Suhu Kritis Pada Sapi Perah Berdasarkan Kemampuan Produksi and Manajemen Pakan." Jurnal Sain Peternakan Indonesia 8 (2): 121-38. doi:10.31186/jspi.id.8.2.121-138.

15. Supranto, Johanes. 2009. "Statistik Teori and Aplikasi Edisi Ketujuh." Jakarta: Erlangga.

16. Susilawati, Trinil, and Aulia Puspita Anugra Yekti. 2018. Teknologi Inseminasi Buatan Menggunakan Semen Cair (Liquid Semen): Solusi Untuk Daerah Yang Tidak Ada/Sulit Nitrogen Cair. Universitas Brawijaya Press.

17. Wolfger, Barbara, Braden J. Manns, Herman W. Barkema, Karen S. SchwartzkopfGenswein, Craig Dorin, and Karin Orsel. 2015. "Evaluating the Cost Implications of a Radio Frequency Identification Feeding System for Early Detection of Bovine Respiratory Disease in Feedlot Cattle." Preventive Veterinary Medicine 118 (4). Elsevier B.V.: 285-92. doi:10.1016/j.prevetmed.2014.12.001.

18. Yani, A, and B P Purwanto. 2006. "Pengaruh Iklim Mikro Terhadap Respons Fisiologis Sapi Peranakan Fries Holland and Modifikasi Lingkungan Untuk Meningkatkan Produktivitasnya (ULASAN)." Media Peternakan 29 (1): 35-46.

19. Yekti, Aulia Puspita Anugra, Trinil Susilawati, Muhammad Nur Ihsan, and Sri Wahyuningsih. 2017. Fisiologi Reproduksi Ternak: Dasar Manajemen Reproduksi. Universitas Brawijaya Press. 